\title{
An Emergency Shift to e-Learning in Health Professions Education: A Comparative Study of Perspectives between Students and Instructors
}

\author{
Afrah Almuwais \\ Department of Rehabilitation Sciences, College of Health and Rehabilitation Sciences, \\ Princess Nourah Bint Abdulrahman University, Riyadh, Saudi Arabia \\ https://orcid.org/0000-0002-2774-868X \\ Samiah Alqabbani \\ Department of Rehabilitation Sciences, College of Health and Rehabilitation Sciences, \\ Princess Nourah Bint Abdulrahman University, Riyadh, Saudi Arabia \\ https://orcid.org/0000-0003-4495-5047

\section{Nada Benajiba} \\ Department of Basic Health Sciences, Deanship of Preparatory Year, Princess \\ Nourah Bint Abdulrahman University, Riyadh, Saudi Arabia \\ https://orcid.org/0000-0002-5533-7626 \\ Fatmah Almoayad* \\ Department of Health Sciences, College of Health and Rehabilitation Sciences, \\ Princess Nourah Bint Abdulrahman University, Riyadh, Saudi Arabia \\ https://orcid.org/0000-0002-8424-5229
}

\begin{abstract}
This is a cross-sectional study which assessed the readiness to shift to e-learning in correlation with perceived effectiveness and satisfaction following the sudden shift caused by the coronavirus disease 2019 (COVID-19) pandemic among students and instructors. The study compared perspectives between instructors $(n=47)$ and students $(n=254)$ at the College of Health and Rehabilitation Sciences (CHRS) at Princess Nourah bint Abdulrahman University (PNU; Riyadh, Kingdom of Saudi Arabia). Data were collected using an online questionnaire using convenient sampling method. The results showed a high level of readiness to shift to e-learning among instructors and students, as well as a positive correlation between perceived effectiveness and satisfaction. However, instructors showed a higher satisfaction level and perceived this shift to be effective more than students. This experience offers a reasonable foundation for any future plans to implement e-learning in health professions education and maximise its benefits without
\end{abstract}

*Corresponding author: Fatmah Almoayad; Email: ftm.myd@gmail.com 
compromising the practical and clinical training provided via face-to-face learning. Further studies are needed to explore e-learning experiences a year after this shift, when educational institutions are expected to have clearer plans and have better prepared for e-learning. In addition, effect of e-learning shift on clinical training outcomes for different health professions is also recommended.

Keywords: e-learning; COVID-19; health professions; Saudi Arabia

\section{Introduction}

Since the beginning of the $21^{\text {st }}$ century, e-learning has been progressively integrated within higher education systems worldwide (Aljaber, 2018; Hiltz \& Turoff, 2005). In Saudi Arabia, health colleges have participated in the e-learning movement and many have embedded blended teaching strategies that combine face-to-face learning with e-learning (Sajid et al., 2016; Zakaria et al., 2013). While an extensive body of literature discusses several types of e-learning - such as distance learning, blended learning and mobile learning - attempts to confirm their effectiveness have been inconclusive in international research, specifically in studies of e-learning in Saudi Arabia (Rajab, 2018). Nevertheless, blended learning has shown effectiveness vis-à-vis skill and knowledge acquisition in health professions education (Liu, et al 2016). Moreover, growing evidence suggests that advances in virtual simulation are benefitting health profession training (Pottle, 2019; Skochelak \& Stack, 2017).

\subsection{The Importance of Preparedness in e-Learning}

As the literature suggests, providing proper and effective e-learning requires advanced planning (Nasiri et al., 2014; Rice \& McKendree, 2014). e-Learning infrastructure and support have been indicated as crucial to successful e-learning experiences (Naveed et al., 2017). This importance was clearly demonstrated when education shifted abruptly to e-learning in the early months of the coronavirus disease 2019 (COVID-19) pandemic.

During this time, the existence of the required infrastructures and preparedness to accommodate this shift to e-learning demonstrated a significant positive impact on the learning process's continuation. Countries with excellent and complete infrastructure were better able to resume the teaching process with minimal or no interruptions (Marinoni et al., 2020). Meanwhile, poor internet connections and a lack of preparedness (such as a lack of electronic devices) were found to present significant obstacles for both students and instructors during this emergency shift to e-learning (Maatuk et al., 2021). Additionally, the literature showed that satisfaction with e-learning is a key factor for the success of e-learning experiences themselves (Bolliger, 2004; Liaw et al., 2007). Al-Samarraie et al. (2018) investigated a unified perception of students' and instructors' satisfaction with an e-learning system, demonstrating that steadily maintained satisfaction with elearning indicates a successful continuation of e-learning. Thus, instructors' ability to utilise a learning management system is influenced by their satisfaction levels (Yengin et al., 2011). On the other hand, students' online readiness had a mediated influence on learning perceptions and course satisfaction (Wei \& Chou, 2020). Gopal et al. (2021) revealed that students' satisfaction positively influenced 
their performance during online education as a result of the pandemic-related lockdown. Moreover, both students' and instructors' satisfaction influenced their motivation in an online environment (Bolliger \& Wasilik, 2009).

A previous study was conducted by Alqabbani et al. (2020) to assess the readiness to shift to online learning at Princess Nourah bint Abdulrahman University's (PNU; Riyadh, Kingdom of Saudi Arabia). It found an excellent existing infrastructure and a high level of readiness among instructors at the university. This study's findings also revealed that satisfaction was positively correlated with perceived effectiveness during the complete shift to e-learning. While this correlation indicated a positive shift experience at the institution, students and instructors at the College of Health and Rehabilitation Sciences (CHRS) within PNU - which offers thirteen allied health speciality programmes (PNU, 2020) - might have had a different experience. This potential difference is due to the nature of learning, which requires hands-on practice to master clinical skills. The unplanned, sudden shift to online learning led to changes in not only theoretical teaching but also practical and clinical training, which have been replaced by videos, online simulation, case study reports and online discussions. As a result, the shift to e-learning might influence both the learning process and learning outcomes (Huang, 2010; Luhanga, 2018; Parandeh et al., 2015). Therefore, assessing satisfaction with e-learning provides insights for educational institutions on identifying areas of improvement in online learning (Bolliger, 2004; Liaw et al., 2007).

\subsection{Students' and Instructors' Complementarity in the Learning Process}

While exploring the unique learning experience during a shift to e-learning is interesting, such investigations can only allow insights via analyses of perceptions' complementarity between students (as learners) and instructors (as teachers) since exploring both learners' and teachers' perspectives can provide comprehensive evaluations of the e-learning experience as one entity (Khan, 2005). Instructors have been very clearly established to represent half of the crucial learning experience via the teaching process for which they are responsible. The other half of the learning experience is based on students' learning process (Ellaway \& Masters, 2008). Hence, both halves of this experience (those of instructors and teachers) are complementary, and their harmony is essential to the learning process.

Mishra et al. (2020) examined both students' and teachers' perceptions of the online learning experience during the COVID-19 pandemic. Their findings revealed that the main factor causing instructors' better motivation compared to students is a belief that online education can proficiently deliver intended learning outcomes. Students, however, reported less interest in and attention to online classes as a new, unfamiliar teaching mode. However, as the literature suggests, while learners report preferences regarding their learning styles, they also tend to adapt their learning to the available teaching strategies, based on the context and motivations (Entwistle, 1997). Recently, Motte-Signoret et al. (2021) indicated that both medical students and their instructors perceived e-learning as a suitable alternative medical education delivery method during the pandemic. 
At the beginning of the COVID-19 pandemic, many academic researchers were interested in studying the emergency shift to e-learning. In this regard, most published studies have highlighted the sudden shift's influence on e-learning's effectiveness. Hence, in addition to analysing this experience, the present study also compares this experience from the perspectives of both students and teachers affiliated with a health college (including 13 different specialities). Furthermore, it emphasises some key factors' importance in determining e-learning's effectiveness under the pandemic's unexpected circumstances. Thus, existing elearning infrastructures and support prior to the COVID-19 pandemic's lockdown-related emergency shift to e-learning, an indicator of readiness for elearning, and perceived satisfaction among students and teachers, were analysed as possible factors influencing the shift's perceived effectiveness. The study's results were, therefore, expected to provide insights into the complexity of this elearning's effectiveness and the necessary considerations of the above-mentioned factors to promote this e-learning as education systems are currently projected to further integration of e-learning in the coming years.

The present study's researchers hypothesised that students and instructors would harbour different perspectives regarding readiness, satisfaction and perceived effectiveness during this shift. Thus, the authors' null hypothesis was that students and instructors would demonstrate similar readiness, satisfaction and perceived effectiveness as a result of this shift.

\subsection{Conceptual Framework}

This research adopted the cognitive theory of learning, which holds that learning is affected by both intrinsic and extrinsic factors (Janelli, 2018). In the field of elearning teaching strategies, cognitive overload, motivation levels and real-life situations are all considered essential factors that affect the learning process (Mödritscher, 2006). In this research context, e-learning was imposed suddenly. The authors sought to explain the supporting environment that contributed to the success of any e-learning experience through a conceptual framework (Figure 1). As the literature has discussed, an appropriate e-learning infrastructure with adequate support significantly affects the continuation and successful achievement of the e-learning process. Thus, ensuring a sufficient level of readiness (preparedness) for both students and instructors positively influences satisfaction levels and, consequently, achieves reasonable levels of perceived elearning effectiveness. The presence of all these elements simultaneously would ensure overall success in a shift to e-learning. Thus, through its mode of learning, the current research obtained insights into the factors that contribute to elearning's continuation. 


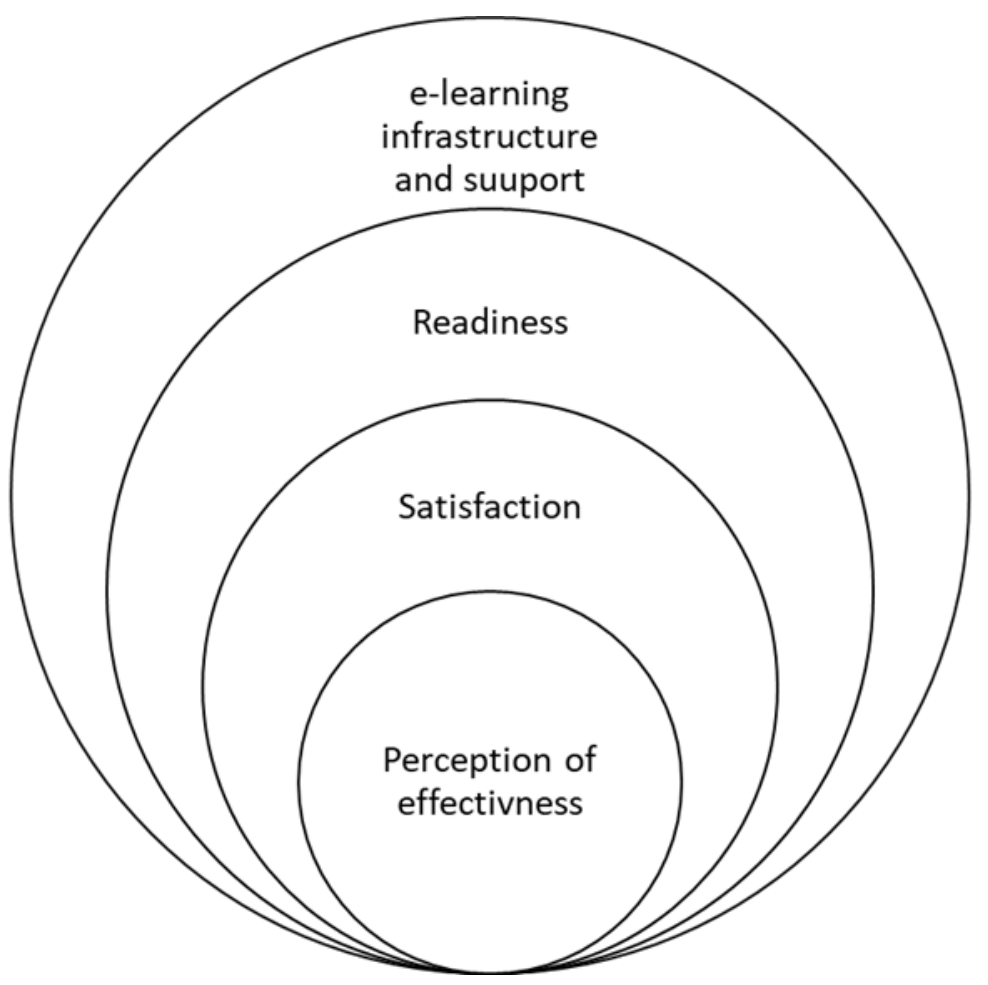

Figure 1: Conceptual framework of the e-learning experience

\section{Methods}

\subsection{Design}

A comparative analytic study was conducted during May 2020. Participants were recruited using a convenient sampling technique. This method was the most efficient method possible, especially during the lockdown period. Questionnaires were available electronically via Microsoft Forms and distributed via the CHRS email lists. To facilitate the dissemination of the study's information and requests to affiliated students, instructors and administrative staff, the CHRS had developed and annually updated a specific e-mail list for each of the abovementioned categories. Hence, the two e-mail lists corresponding, respectively, to instructors and students were used to solicit participation in this study after consent was obtained from all participants. The email was sent twice to each person on the e-mail lists the first time as an invitation to participate in the study and the second time as a gentle reminder to encourage further participation. The emails directed to students were sent from the official email address of the ViceDeanship of Student Affairs. Meanwhile, the emails directed to instructors were sent from the official email address of the Vice-Deanship of Academic Affairs. The lists' inclusion criteria were instructors and students who were actively engaged in learning or teaching during the semester when the sudden shift to e-learning occurred. The study sample comprised 47 of 66 instructors and 254 of 720 students at the CHRS. The survey rates were $35 \%$ and $71 \%$ among students and instructors, respectively. However, note that prospective participants' ability to submit answers was deactivated soon after the survey met its required representative numbers of participants, which were $n=45$ (of 66) for instructors and $n=251$ for students. These values were calculated based on a confidence level of $95 \%$ and a margin of error of $\pm 5 \%$. Ethical approval (IRB Log Number 20-0162) was obtained 
from the institutional review board at PNU before this research was conducted. Participation in the study was voluntary. Anonymity and confidentiality were maintained, and consent to participate was obtained from participants at the beginning of the study's questionnaires.

\subsection{Research Instruments}

Two questionnaires were designed for this project's data collection. The first questionnaire was directed towards instructors (Appendix 1) while the second questionnaire was directed towards students (Appendix 2). The questionnaires were adapted from a previous study that had been conducted by the present research team (Alqabbani et al., 2020) with some adjustments to suit the current study's aim. The two questionnaires comprised four similar sections, including general characteristics, the readiness to shift to e-learning, the perceived effectiveness of learning or teaching after the shift to e-learning and satisfaction with this shift. Since the study aimed to compare instructors' perspectives and students' perspectives, the questionnaires' three latter sections were designed to measure the same parameters; therefore, they comprised the same questions. However, the term "teaching" was applied to instructors, and the term "learning" was applied to students. The sections are described in detail in the following four paragraphs.

Section 1 comprised three questions for instructors and four questions for students. For instructors, this section collected data about academic rank, years of teaching experience and numbers of courses taught. For students, the collected data were grade point averages (GPAs), levels of study, academic levels and programmes of study.

Section 2 contained five questions to measure the readiness to switch to e-learning by assessing experiences with e-learning platforms, as well as the feasibility and accessibility of e-learning platforms prior to the COVID-19 pandemic. These questions focused on whether instructors and students had electronic devices, proper internet access and diverse ways to interact with each other-including both face-to-face and telecommunication methods-in addition to questions about the use of different BlackBoard BB features. Each answer that reflected the use of e-learning platforms or a supporting atmosphere was given a readiness score of 1 . The total readiness score was calculated by adding the values of the scores for each question. The maximum readiness score was 9 , and the minimum readiness score was 0 .

Section 3 comprised a total of 14 questions to evaluate how both instructors and students perceived e-learning experiences' effectiveness after the pandemicrelated shift. These questions pertained to e-learning experiences and quality, the extent to which e-learning supported independent learning and helped achieve goals, students' motivation, communication between students and instructors, time management and organisation. A five-point Likert scale (Likert, 1932) was employed in which the highest score, 5, indicated strongly agree, a score of 4 indicated agree, a score of 3 indicated neutral, a score of 2 indicated disagree and the lowest score, 1, indicated strongly disagree. 
Section 4 comprised five questions to assess satisfaction levels among students and instructions regarding their learning or teaching experiences after the shift to e-learning. These questions pertaining to satisfaction assessed overall experiences related to teaching or learning, the clarity of remote teaching or learning instructions, the accessibility of remote teaching or learning materials, the simplicity of remote teaching or learning tools and the support or feedback received during remote teaching or learning. The scale was also based on a fivepoint Likert scale (Likert, 1932) in which the highest score of, 5, indicated very satisfied, a score of 4 indicated satisfied, a score of 3 indicated neutral, a score of 2 indicated unsatisfied and the lowest score, 1, indicated not at all satisfied.

The internal consistency of the questionnaires' reliability was tested using Cronbach's a, as described by Bolarinwa (2015). The obtained a value was equal for instructors and students, as follows: perceived e-learning effectiveness (14 questions; 0.85, 0.88) and satisfaction (five questions; 0.78, 0.79). These values showed that the questionnaire's reliability was good, indicating that the items effectively measured the same aspects. Additionally, the questionnaires were piloted with $10 \%$ of the study's respective samples. This pilot approach involved testing the questionnaires on a smaller scale with a sample of the study population before their distribution. This step was crucial since it helped ensure that the questionnaires adequately measured the items for which they were designed and that respondents provided feedback. Respondents' feedback was requested on the appropriateness, length and wording of the questionnaires and the instructions, as well as the questions' adequacy, as recommended by Marshall (2005).

\subsection{Statistical Analysis}

The collected data were analysed using Statistical Package for Social Sciences software (SPSS version 22). Descriptive statistics were used to present the results in frequencies and percentages. Normal data distribution was assessed using Kolmogorov-Smirnov and Shapiro-Wilk tests. An independent $t$-test was conducted to evaluate differences in means between instructors and students. For instructors, Pearson's correlation coefficient was applied to determine the correlation among teaching experience, academic rank, the readiness to shift to elearning, the perceived effectiveness of teaching after the shift to e-learning and satisfaction with e-learning. For students, to assess the correlation among GPAs, academic levels, the readiness to switch to e-learning, the perceived effectiveness of learning and satisfaction with the shift to e-learning, Pearson's correlation coefficient was used. The statistical significance for these analyses was set to $p \leq$ 0.05 .

\section{Results}

\subsection{General Characteristics}

In total, 47 instructors and 254 students participated in this study. Of the participating instructors, $65.9 \%$ had more than five years of teaching experience and $80.9 \%$ had a PhD. The numbers of courses taught by the instructors were two and three, representing $34 \%$ and $31.9 \%$ of participating instructors, respectively. The majority of participating students were enrolled in courses at the Rehabilitation Sciences department $(35.8 \%)$ or Health Sciences department 
(45.3\%). Most students (95.5\%) had an excellent (> 4.5) or very good (3.75-4.4) GPA (Table 1).

Table 1. Characteristics of the study sample

\begin{tabular}{|c|c|c|}
\hline & $\%$ & $n$ \\
\hline \multicolumn{3}{|l|}{ Instructors $(n=47)$} \\
\hline \multicolumn{3}{|l|}{ Academic rank } \\
\hline Teaching assistant & 10.6 & 5 \\
\hline Lecturer & 8.5 & 4 \\
\hline Assistant professor & 61.7 & 29 \\
\hline Associate professor & 14.9 & 7 \\
\hline Professor & 4.3 & 2 \\
\hline \multicolumn{3}{|c|}{ Teaching experience (years) } \\
\hline $0-2$ & 19.1 & 9 \\
\hline $3-5$ & 14.9 & 7 \\
\hline $6-10$ & 34.0 & 16 \\
\hline$>10$ & 31.9 & 15 \\
\hline \multicolumn{3}{|l|}{ Number of courses taught } \\
\hline 1 & 19.1 & 9 \\
\hline 2 & 34.0 & 16 \\
\hline 3 & 31.9 & 15 \\
\hline 4 & 6.4 & 3 \\
\hline 5 & 8.5 & 4 \\
\hline \multicolumn{3}{|l|}{ Students $(n=254)$} \\
\hline \multicolumn{3}{|l|}{ Department } \\
\hline Rehabilitation Sciences & 35.8 & 91 \\
\hline Health Sciences & 45.3 & 115 \\
\hline Communication Sciences & 8.7 & 22 \\
\hline Radiology Sciences & 10.2 & 26 \\
\hline \multicolumn{3}{|l|}{ GPA* } \\
\hline Excellent (> 4.5) & 41.3 & 105 \\
\hline Very good (3.75-4.4) & 50.4 & 128 \\
\hline Good (2.5-3.74) & 5.5 & 14 \\
\hline Poor $(<2.5)$ & 0.0 & 0 \\
\hline \multicolumn{3}{|l|}{ Academic level } \\
\hline $3-4$ & 31.9 & 81 \\
\hline $5-6$ & 25.2 & 64 \\
\hline $7-8$ & 31.1 & 79 \\
\hline $9-10$ & 5.9 & 15 \\
\hline $11-12$ & 5.9 & 15 \\
\hline
\end{tabular}

*GPA: Grade point average.

\subsection{The Readiness to Shift to e-Learning}

Vis-à-vis their readiness to shift to e-learning, all participating instructors $(100 \%)$ and the majority of participating students $(97.6 \%)$ reported that they owned electronic devices. Additionally, 93.6\% of instructors and $94.5 \%$ of students reported having proper internet access. Students and instructors seemed to use 
similar ways to interact, including office hours, emails, Telegram, WhatsApp and communication during lectures, and no significant differences were reported in this regard $(p>0.05)$. Therefore, the authors' null hypothesis was verified. In contrast, the use of BB was significantly higher (more than twice as high) among instructors $(61.7 \%)$ compared to students $(29.9 \%) ; p<0.00001$. However, an analysis of BB use features suggested that students used certain features more than instructors, particularly assignments, virtual classes and quizzes or exams ( $p$ $=0.01, p=0.00022$ and $p<0.00001$, respectively). The use of discussion boards and the uploading of course materials were almost equal among students and instructors since no significant difference was found in these regards $(p>0.05)$. The calculated overall mean readiness scores showed that the obtained values were equal to $6.2 \pm 1.9$ for instructors and $6.5 \pm 1.5$ for students. The difference between the overall mean readiness scores was not significant between instructors and students $(p=0.187$ ) (Table 2). This finding shows that instructors and students at the CHRS were equally prepared for the sudden shift to e-learning as a result of the COVID-19 pandemic.

Table 2: Frequency (in percentages; $n$ ) of students' and instructors' interactions and readiness

\begin{tabular}{|l|l|l|l|}
\hline & Instructors $(n=47)$ & \multicolumn{1}{|c|}{ Students $(n=254)$} & \multicolumn{1}{c|}{$p$-value } \\
\hline Electronic device & $100(47)$ & $97.6(248)$ & 0.29 \\
\hline Proper internet & $93.6(44)$ & $94.5(240)$ & 0.81 \\
\hline Interaction & & & \\
\hline Office hours & $87.2(41)$ & $77.6(197)$ & 0.13 \\
\hline Email & $93.6(44)$ & $90.6(230)$ & 0.49 \\
\hline BB & $61.7(29)$ & $29.9(76)$ & $<0.00001$ \\
\hline Telegram & $6.4(3)$ & $7.5(19)$ & 0.78 \\
\hline WhatsApp & $42.6(20)$ & $40.6(103)$ & 0.79 \\
\hline Lectures only & $19.1(9)$ & $18.9(48)$ & 0.96 \\
\hline Blackboard features & & & \\
\hline Virtual classes & $23.4(11)$ & $52.8(134)$ & 0.00022 \\
\hline Discussion board & $51.1(24)$ & $44.9(114)$ & 0.44 \\
\hline Quizzes or exams & $42.6(20)$ & $73.6(187)$ & $<0.00001$ \\
\hline Uploading course materials & $85.1(40)$ & $83.9(213)$ & 0.83 \\
\hline Submitting assignments & $72.3(34)$ & $87.0(221)$ & 0.01 \\
\hline Overall readiness & $\mathbf{6 . 2 \pm 1 . 9}$ & $\mathbf{6 . 5} \pm \mathbf{1 . 5}$ & $\mathbf{0 . 1 8 7}$ \\
\hline
\end{tabular}

Z-score

\subsection{Satisfaction}

Table 3 summarises the study's results regarding satisfaction with e-learning among instructors and students at the CHRS. The highest score was obtained for accessibility of e-learning materials for both instructors $(4.3 \pm 0.7)$ and students $(4.0 \pm$ 1.0). Meanwhile, the lowest score was obtained for e-learning experience for instructors $(3.7 \pm 1.1)$ and students $(3.4 \pm 1.1)$. A similar low score was obtained for students in support or feedback received during e-learning (3.4 \pm 1.3$)$. For all questions related to satisfaction, the average scores for instructors exceeded the corresponding scores for students. Hence, the differences were significant for $e$ learning experience and clarity of e-learning instructions between the two groups ( $p=$ 0.048 and $p=0.011$, respectively). Consequently, the mean score for overall satisfaction with e-learning was significantly higher for instructors than students 
$(4.1 \pm .0 .6$ versus $3.7 \pm 0.8 ; p<0.001)$. Therefore, the authors' null hypothesis was rejected. These results demonstrate that, unlike the readiness to shift to e-learning (which was similar between the study's two populations), instructors were more satisfied with their e-learning experiences than students.

Table 3: Satisfaction with e-learning among instructors and students at the College of Health and Rehabilitation Sciences: Mean \pm SD

\begin{tabular}{|l|c|c|c|}
\hline & Instructors $(n=47)$ & Students $(n=254)$ & $p$-value \\
\hline Overall satisfaction & $\mathbf{4 . 1} \mathbf{0 . 6}$ & $\mathbf{3 . 7} \pm \mathbf{0 . 8}$ & $<\mathbf{0 . 0 0 1}$ \\
\hline e-Learning experience & $3.7 \pm 1.1$ & $3.4 \pm 1.1$ & 0.048 \\
\hline Clarity of e-learning instructions & $4.0 \pm 0.9$ & $3.6 \pm 1.1$ & 0.011 \\
\hline Accessibility of e-learning materials & $4.3 \pm 0.7$ & $4.0 \pm 1.0$ & 0.057 \\
\hline Simplicity of e-learning tools & $4.2 \pm 0.7$ & $3.9 \pm 1.1$ & 0.251 \\
\hline $\begin{array}{l}\text { Support or feedback received during e- } \\
\text { learning }\end{array}$ & $4.1 \pm 0.9$ & $3.4 \pm 1.3$ & 0.685 \\
\hline
\end{tabular}

$P$-values were calculated using an independent $t$-test.

$5=$ very satisfied. $1=$ not at all satisfied.

\subsection{Perceived Effectiveness}

Table 4 presents the study's results regarding the perceived effectiveness of learning or teaching after the pandemic-related e-learning shift among both instructors and students. For both instructors and students, the lowest mean scores obtained pertained to shifting to e-learning is more enjoyable than face-to-face learning at $2.1 \pm 1.1$ and $2.3 \pm 1.3$, respectively. The highest score was obtained for shifting to e-learning introduced me to different online applications, which helped my teaching/learning, at $4.4 \pm 0.7$ for instructors and $3.5 \pm 0.8$ for students. The score for shifting to e-learning helped students become independent learners was significantly higher among students $(p=0.037)$. The mean scores of the perception-related items were higher for instructors than students. Among instructors, the average scores for seven items were significantly higher $(p<0.05)$ than students' corresponding scores: shifting to e-learning gave me a positive teaching or learning experience; improved the quality of my teaching or learning; helped me be better organised; introduced me to different online applications, which helped my teaching or learning; introduced me to a variety of new assessment methods; a good motivation for teaching or learning; and helps deliver or explain the subject's material well. The authors' null hypothesis was rejected since the overall average score for instructors' perceived teaching experiences exceeded the mean score for students' perceived learning $(3.3 \pm .0 .6$ versus $2.9 \pm .0 .6 ; \mathrm{p}<0.001)$ (Table 4$)$. This finding indicates that instructors had better e-learning experiences than students.

Table 4: The perceived effectiveness of learning or teaching after the shift to elearning among instructors and students at the College of Health and Rehabilitation Sciences: Mean \pm SD

\begin{tabular}{|c|c|c|c|}
\hline & $\begin{array}{l}\text { Instructors } \\
(n=47)\end{array}$ & $\begin{array}{l}\text { Students } \\
(n=254)\end{array}$ & $p$-value \\
\hline $\begin{array}{l}\text { Overall perceived effectiveness of shifting to e- } \\
\text { learning }\end{array}$ & $3.3 \pm 0.6$ & $3.0 \pm 0.6$ & $<0.001^{*}$ \\
\hline It gave me a positive teaching/learning experience. & $3.7 \pm 0.9$ & $2.8 \pm 1.0$ & $<0.001^{*}$ \\
\hline It improved the quality of my teaching/learning. & $3.1 \pm 0.9$ & $2.5 \pm 1.0$ & $<0.001^{*}$ \\
\hline It helped me be better organised. & $3.2 \pm 0.9$ & $2.9 \pm 1.0$ & $0.04^{*}$ \\
\hline
\end{tabular}




\begin{tabular}{|c|c|c|c|}
\hline $\begin{array}{l}\text { It improved the communication between students and } \\
\text { instructors. }\end{array}$ & $3.2 \pm 1.0$ & $3.1 \pm 0.9$ & 0.34 \\
\hline It helped students become independent learners. & $3.3 \pm 1.1$ & $3.7 \pm 0.7$ & $0.037^{*}$ \\
\hline It helped me work at my own speed. & $3.6 \pm 1.1$ & $3.6 \pm 0.7$ & 0.787 \\
\hline It enabled me to achieve course learning outcomes. & $2.9 \pm 1.1$ & $2.9 \pm 1.1$ & 0.978 \\
\hline $\begin{array}{l}\text { It introduced me to different online applications, which } \\
\text { helped my teaching or learning. }\end{array}$ & $4.4 \pm 0.7$ & $3.5 \pm 0.8$ & $<0.001^{*}$ \\
\hline $\begin{array}{l}\text { It introduced me to a variety of new assessment methods, } \\
\text { which affected my teaching or learning in positively. }\end{array}$ & $4.0 \pm 1.0$ & $3.1 \pm 1.0$ & $<0.001^{*}$ \\
\hline It helped me manage my time more effectively. & $3.3 \pm 1.0$ & $3.1 \pm 1.2$ & 0.209 \\
\hline $\begin{array}{l}\text { Remote learning is a good motivation for teaching or } \\
\text { learning. }\end{array}$ & $4.0 \pm 0.8$ & $2.6 \pm 1.0$ & $<0.001^{*}$ \\
\hline $\begin{array}{l}\text { Remote learning helps deliver or explain the subject's } \\
\text { material well. }\end{array}$ & $3.1 \pm 1.0$ & $2.5 \pm 1.1$ & $0.001^{*}$ \\
\hline $\begin{array}{l}\text { Remote learning is more enjoyable than face-to-face } \\
\text { learning. }\end{array}$ & $2.1 \pm 1.1$ & $2.3 \pm 1.3$ & 0.358 \\
\hline $\begin{array}{l}\text { It made me prefer to teach more courses via remote } \\
\text { learning. }\end{array}$ & $2.6 \pm 1.1$ & $2.8 \pm 1.2$ & 0.251 \\
\hline
\end{tabular}

$P$-values were calculated using an independent $t$-test.

$5=$ strongly agree. $1=$ strongly disagree.

\subsection{Correlations between e-Learning Readiness, Satisfaction and Perceived Effectiveness}

Table 5 and Table 6 summarise the correlations between the different parameters investigated for students and instructors, respectively. Pearson's correlation coefficient revealed a strong positive correlation between satisfaction with perceived teaching or learning experiences after the shift to e-learning and the perceived effectiveness of learning or teaching for students $(r=0.68, p<0.001)$, as well as a moderate correlation for instructors $(r=0.38, p=0.008)$. The readiness to switch to e-learning was weakly correlated with satisfaction for students only ( $r=$ $0.217, p<0.001)$. Instructors' academic rank exhibited a moderate correlation with such readiness $(r=0.468, p=0.001)$ and perceived effectiveness $(r=0.340, p=$ 0.019). Interestingly, for both students and instructors, the perceived effectiveness of learning or teaching after the shift to e-learning significantly correlated with elearning satisfaction, unlike the readiness to switch to e-learning. This finding might indicate satisfaction's importance as a principal factor in the learning process's success.

Table 5: Correlation between the different parameters investigated among College of Health and Rehabilitation Sciences instructors $(n=47)$

\begin{tabular}{|l|l|l|l|l|l|}
\hline & $\begin{array}{l}\text { Teaching } \\
\text { experience }\end{array}$ & $\begin{array}{l}\text { Academic } \\
\text { rank }\end{array}$ & Readiness & $\begin{array}{l}\text { Perceived } \\
\text { effectiveness }\end{array}$ & Satisfaction \\
\hline Teaching experience & 1 & 0.265 & 0.255 & -0.149 & 0.105 \\
\hline Academic rank & - & 1 & $0.468^{* *}$ & $0.340^{*}$ & 0.246 \\
\hline Readiness & - & - & 1 & 0.085 & 0.11 \\
\hline Perceived effectiveness & - & - & - & 1 & $0.383^{* *}$ \\
\hline Satisfaction & - & - & - & - & 1 \\
\hline
\end{tabular}

Correlations were calculated using Pearson's test; * $p<0.05$ and ${ }^{* *} p<0.01$ 
Table 6: Correlation between the different parameters investigated among College of Health and Rehabilitation Sciences students $(n=254)$

\begin{tabular}{|l|c|l|c|c|c|}
\hline & GPA & $\begin{array}{l}\text { Academic } \\
\text { level }\end{array}$ & Readiness & $\begin{array}{l}\text { Perceived } \\
\text { effectiveness }\end{array}$ & Satisfaction \\
\hline GPA & 1 & -0.085 & 0.019 & -0.03 & -0.121 \\
\hline Academic level & - & 1 & 0.045 & 0.028 & -0.068 \\
\hline Readiness & - & - & 1 & $0.682^{* *}$ & 0.108 \\
\hline Perceived effectiveness & - & - & - & 1 & $0.217^{* *}$ \\
\hline Satisfaction & - & - & - & - & 1 \\
\hline
\end{tabular}

Correlations were calculated using the Pearson's correlation coefficient; ${ }^{* *} p<0.01$.

\section{Discussion}

This study aimed to provide an understanding of experiences related to the pandemic-related abrupt shift to e-learning from the perspectives of both teachers and students, assessing how readiness may affect these experiences. The study's findings revealed a high level of readiness to shift to e-learning among both instructors and students, as well as a positive correlation between perceived effectiveness and satisfaction. However, instructors showed significantly higher satisfaction levels $(p<0.001)$ and perceived this experience to be more effective than students had done.

Based on the study's conceptual framework, these results indicate that a high level of readiness among students and instructors-which led to satisfactioncorrelates with the shift to e-learning's perceived effectiveness. Both students and instructors agreed that e-learning provided an opportunity to work at their own pace, manage their time more effectively and improve their interactions. The shift to e-learning introduced instructors to a variety of previously not employed online applications with which to communicate with students. Thus, this expansion of the communication tools applied during e-learning improved interactions between instructors and their students. Such interactions enhance students' engagement and satisfaction with online courses, as the literature has previously shown (Beaudoin et al., 2009; Dixson, 2010). Moreover, students and instructors harboured similar perspectives on the effectiveness of time management and work pacing. e-Learning offers flexible teaching and learning opportunities for more self-directed learning (Albarrak, 2011). Although elearning forces instructors to work outside their comfort zones, instructors expressed high satisfaction levels. Instructors were more satisfied with their elearning experiences than students, which may have been due to $\mathrm{BB}^{\prime}$ 's regular training and the accessible technical support provided by the university to all faculty members (Alqabbani et al., 2020). Additionally, Maatuk et al. (2021) explained that lower satisfaction levels among students had resulted from the increased workload caused by e-learning. This influence could be particularly present during the emergency shift to e-learning because of the COVID-19 pandemic. Thus, as cognitive load theorists have suggested, instructors should consider the amount of work they assign their students and divide information into chunks so that their students can have more effective learning experiences (Van Merrienboer \& Ayres, 2005). Congruent results by Sørebø and Sørebø (2008) indicated that instructors' perceived usefulness of e-learning and satisfaction are 
useful in introducing appropriate elements for successful planning to achieve effective e-learning.

The current study's results indicate that e-learning helped students become independent learners, showing that students' autonomy and responsibility vis-àvis their learning increased after the shift to e-learning. Consistent with this finding, Joo et al. (2011) and Yang and Cao (2013) concluded that learners' realisation of their e-learning responsibilities predicted learning flows and steadiness, as well as success. Additionally, e-learning facilitates the achievement of learning outcomes and learners' development, supporting students' autonomy (Algahtani, 2011). However, Lawrence (2018) claimed that students' evaluations of their learning's effectiveness have provided invalid data, and Lawrence considered such evaluations a poor measurement of learning effectiveness. This claim was supported by a meta-analysis showing no significant correlation between students' teaching evaluations and learning (Uttl et al., 2017). Interestingly, despite students' low perception of effectiveness, they considered e-learning useful in increasing their autonomy and responsibility vis-à-vis their learning, which is a sign of successful learning (Joo et al., 2011; Yang \& Cao, 2013).

In Saudi Arabia, e-learning started suddenly during the middle of the second semester of the 2019-2020 academic year, without any prior planning, in response to the COVID-19 pandemic-related lockdowns. Yet, advanced planning and infrastructure are key determinants of successful e-learning (Algahtani, 2011; Aljaber, 2018; Edwards \& McKinnell, 2007; Nasiri et al., 2014; Rice \& McKendree, 2014). Negative attitudes were observed among both students and instructors in terms of preferring face-to-face learning and not enjoying e-learning. While the sudden shift to e-learning was expected to influence e-learning's effectiveness, this impact was more apparent among students than instructors since students harboured lower perceptions of e-learning's effectiveness. A possible explanation for this difference is courses' clinical and practical nature, which Corter et al. (2011) by confirming that students' motivations were higher among a hands-on group than at simulation distance laboratory. Additionally, some studies have suggested that e-learning may be avoided since it cannot replace face-to-face learning, especially in medical education (Albarrak, 2011; Rajab, 2018), given medical academics' independent and conservative nature (Lane, 2007). Another explanation could be the difficulty of achieving intended learning outcomes, which led to improper planning for a complete e-learning mode since courses were designed to be delivered in a traditional mode.

Moreover, students' experience of the shift to e-learning were found to be negative. Hence, their introduction to new assessment methods could be more stressful since they were not trained in these methods; only $29.9 \%$ of students had used BB before the studied shift to e-learning. After this shift, classic assessment methods changed to electronic alternatives and a new grade distribution occurred. Therefore, the lack of preparation at both the technical level and the psychological level-as well as concerns about lower grades-could have contributed to this negative perception. Furthermore, the overall increase in anxiety during the COVID-19 pandemic could also have influenced learning (Almoayad et al., 2020; Cao et al., 2020; Gallagher \& Schleyer, 2020; Saddik et al., 
2020). Students were also found not to have fully understood e-learning course material, marking a significant difference from instructors' perception. This finding could be associated with students' preference for face-to-face learning over e-learning and a lack of enjoyment, as previously discussed. Additionally, regarding the nature of health-profession courses, students were suddenly introduced to various substitutes to clinical training-such as simulated and recorded cases - which are effective in health professions education (Albarrak, 2011). Bao (2020) claimed that instructors should break down e-learning material and adopt a modular teaching method to increase students' involvement in elearning.

The current study has shown that students and instructors were ready to shift to e-learning, demonstrating satisfaction with the support provided, which led to a positive perception of this shift. However, a lack of planning was highlighted in the negative perceptions among learners and teachers. The continued use of traditional methods of teaching, assessing and learning among both teachers and learners - without proper modulation for e-learning - could explain e-learning's perceived failure to help achieve intended learning outcomes. Thus, given the lack of clarity about education's future and the expected extension of e-learning, and to promote successful e-learning experiences in health professions education, both instructors and students must adopt new teaching and learning approaches and share their decisions regarding the e-learning planning process. This approach is essential to overcome gaps among the main education stakeholders, especially in different healthcare specialities, which may require various educational strategies and learning styles.

\subsection{Limitations}

Although this study explored e-learning-related perceptions among health professions instructors and students, it did not differentiate between specialities vis-à-vis the nature of clinical courses taught through e-learning. Moreover, the clinical and practical training conducted after the shift to e-learning using online alternatives, such as simulation, were not tested for their effectiveness. The other limitation of this study is the convenient sampling technique used during the project's data collection. While the study's findings cannot be generalised, they could nonetheless serve as a basis for adequate planning to develop a complete, successful e-learning model in medical education.

\section{Conclusion}

This study aimed to assess the level of readiness for e-learning, perceived effectiveness and satisfaction regarding e-learning experiences among both students and instructors at a college with courses in 13 health professions during the COVID-19 pandemic. The results showed that the readiness to shift to elearning was high among both students and instructors, positively correlating with satisfaction-which, in turn, positively correlated with perceived effectiveness. The study's main findings are that e-learning provided similar opportunities for both students and instructors at the CHRS to work at their own pace, manage their time more effectively and improve their interactions. On the other hand, the sudden shift to e-learning was not enjoyable, and it did not help students or instructors achieve course learning outcomes; both groups would 
have preferred to have more courses delivered via face-to-face learning. Throughout these findings, respondents' experiences highlighted proper planning's importance to e-learning. However, a complete e-learning mode might not be suitable for all aspects of health professions education - especially not for courses that require practical skills. By analysing both positive and negative elearning perceptions during experiences after the sudden shift to e-learning among instructors and students at the CHRS, this study also recommended planning for a blended learning approach integrating face-to-face learning and elearning to best achieve intended learning outcomes. One of this study's main recommendations is to plan for e-learning. Utilising different approaches and teaching strategies and considering dividing information into chunks and tasks to avoid overloading students, is recommended to obtain greater benefits from the shift to e-learning during the COVID-19 pandemic, such as better time management and increased independence. Strategies such as team-based learning or flipped classes may be more enjoyable for both teachers and learners during elearning. Additionally, some assessment methods - such as open-book exams and oral exams - may be more suitable for e-learning than traditional assessment methods. Moreover, blended learning could be suitable to address intended learning outcomes and increase motivation during clinical and practical training while maintaining e-learning's benefits. Based on this study, the authors recommend further research exploring the e-learning shift's effect on clinical training outcomes for different health professions. Studies on e-learning experiences a year after this shift, when educational institutions are expected to have clearer plans and have better prepared for e-learning, are also recommended.

\section{Acknowledgements}

This research was funded by the Deanship of Scientific Research at Princess Nourah bint Abdulrahman University through the Fast-track Research Funding Program.

\section{Declaration of Interest Statement}

The authors declare no conflicts of interest.

\section{References}

Al-Samarraie, H., Teng, B. K., Alzahrani, A. I., \& Alalwan, N. (2018). E-learning continuance satisfaction in higher education: a unified perspective from instructors and students. Studies in higher education, 43(11), 2003-2019. https:// doi.org/10.1080/03075079.2017.1298088

Albarrak, A. (2011). E-learning in medical education and blended learning approach. learning, 13, 14-20. https://www.semanticscholar.org/paper/E-learning-inMedical-Education-and-BlendedAlbarrak/6f7fac687fe689a4166bf1eab385eebcf3b12ab7

Algahtani, A. (2011). Evaluating the E ectiveness of the E-learning Experience in Some Universities in Saudi Arabia from Male Students' Perceptions Durham University]. Durham, UK. http:/ / etheses.dur.ac.uk/3215/

Aljaber, A. (2018). E-learning policy in Saudi Arabia: Challenges and successes. Research in Comparative and International Education, 13(1), 176-194. https://doi.org/10.1177/1745499918764147 
Almoayad, F., Almuwais, A., Alqabbani, S. F., \& Benajiba, N. (2020). Health Professional Students' Perceptions and Experiences of Remote Learning During the COVID-19 Pandemic. International Journal of Learning, Teaching and Educational Research, 19(8), 313-329. https://doi.org/10.26803/ijlter.19.8.17

Alqabbani, S., Almuwais, A., Benajiba, N., \& Almoayad, F. (2020). Readiness towards emergency shifting to remote learning during COVID-19 pandemic among university instructors. E-Learning and Digital Media. https:// doi.org/10.1177/2042753020981651

Bao, W. (2020). COVID-19 and online teaching in higher education: A case study of Peking University. Human Behavior and Emerging Technologies, 2(2), 113-115. https:// doi.org/10.1002/hbe2.191

Beaudoin, M., Kurtz, G., \& Eden, S. (2009). Experiences and opinions of e-learners: What works, what are the challenges, and what competencies ensure successful online learning. Interdisciplinary Journal of E-Learning and Learning Objects, 5(1), 275-289. https://www.learntechlib.org/p/44836/

Bolarinwa, O. A. (2015). Principles and methods of validity and reliability testing of questionnaires used in social and health science researches. Nigerian Postgraduate Medical Journal, 22(4), https://www.npmj.org/text.asp?2015/22/4/195/173959

Bolliger, D. U. (2004). Key factors for determining student satisfaction in online courses. International Journal on E-learning, 3(1), 61-67. https://www.learntechlib.org/p/2226/

Bolliger, D. U., \& Wasilik, O. (2009). Factors influencing faculty satisfaction with online teaching and learning in higher education. Distance Education, 30(1), 103-116. https://doi.org/10.1080/01587910902845949

Cao, W., Fang, Z., Hou, G., Han, M., Xu, X., Dong, J., \& Zheng, J. (2020). The psychological impact of the COVID-19 epidemic on college students in China. Psychiatry research, 112934. https://doi.org/10.1016/j.psychres.2020.112934

Corter, J. E., Esche, S. K., Chassapis, C., Ma, J., \& Nickerson, J. V. (2011). Process and learning outcomes from remotely-operated, simulated, and hands-on student laboratories. Computers \& Education, 57(3), 2054-2067. https://doi.org/10.1016/j.compedu.2011.04.009

Dixson, M. D. (2010). Creating effective student engagement in online courses: What do students find engaging? Journal of the Scholarship of Teaching and Learning, 1-13. https://eric.ed.gov/?id=EJ890707

Edwards, A., \& McKinnell, S. (2007). Moving from dependence to independence: the application of e-learning in higher education. In A. Campbell \& L. Norton (Eds.), Learning, teaching and assessing in higher education: Developing reflective practice (pp. 68-79). Learning matter Ltd.

Ellaway, R., \& Masters, K. (2008). AMEE Guide 32: e-Learning in medical education Part 1: Learning, teaching and assessment. Medical teacher, 30(5), 455-473. https://doi.org/10.1080/01421590802108331

Entwistle, N. (1997). Contrasting perspectives on learning. The experience of learning, 2, 322.

Gallagher, T. H., \& Schleyer, A. M. (2020). “We Signed Up for This!” - student and trainee responses to the COVID-19 pandemic. New England Journal of Medicine. https:// doi.org/10.1056/NEJMp2005234

Gopal, R., Singh, V., \& Aggarwal, A. (2021). Impact of online classes on the satisfaction and performance of students during the pandemic period of COVID 19. Educ Inf Technol (Dordr), 1-25. https:/ / doi.org/10.1007/s10639-021-10523-1 
Hiltz, S. R., \& Turoff, M. (2005). Education goes digital: The evolution of online learning and the revolution in higher education. Communications of the ACM, 48(10), 59-64. https://doi.org/10.1145/1089107.1089139

Huang, L.-S. (2010). Seeing eye to eye? The academic writing needs of graduate and undergraduate students from students' and instructors' perspectives. Language Teaching Research, 14(4), 517-539. https:/ / doi.org/10.1177/1362168810375372

Janelli, M. (2018). E-learning in theory, practice, and research. Вопросы образования(4). https:// doi.org/10.17323/1814-9545-2018-4-81-98

Joo, Y. J., Lim, K. Y., \& Kim, E. K. (2011). Online university students' satisfaction and persistence: Examining perceived level of presence, usefulness and ease of use as predictors in a structural model. Computers \& Education, 57(2), 1654-1664. https://doi.org/10.1016/j.compedu.2011.02.008

Khan, B. H. (2005). Managing e-learning: Design, delivery, implementation, and evaluation. Information Science Publishing.

Lane, I. F. (2007). Change in higher education: Understanding and responding to individual and organizational resistance. Journal of Veterinary Medical Education, 34(2), 85-92. https://doi.org/10.3138/jvme.34.2.85

Lawrence, J. W. (2018). Student evaluations of teaching are not valid. American Association of University Professors. https:// www.aaup.org/comment/4781\#.YMkMtKgzaUk

Liaw, S.-S., Huang, H.-M., \& Chen, G.-D. (2007). Surveying instructor and learner attitudes toward e-learning. Computers \& Education, 49(4), 1066-1080. https://doi.org/10.1016/j.compedu.2006.01.001

Likert, R. (1932). A technique for the measurement of attitudes. Archives of psychology.

Luhanga, F. L. (2018). The traditional-faculty supervised teaching model: Nursing faculty and clinical instructors' perspectives. Journal of Nursing Education and Practice, 8(6), 124-137. https://doi.org/doi.org/10.5430/jnep.v8n6p124

Maatuk, A. M., Elberkawi, E. K., Aljawarneh, S., Rashaideh, H., \& Alharbi, H. (2021). The COVID-19 pandemic and E-learning: challenges and opportunities from the perspective of students and instructors. J Comput High Educ, 1-18. https:// doi.org/10.1007/s12528-021-09274-2

Marinoni, G., Land, H. V T., \& Jensen, T. (2020). THE IMPACT OF COVID-19 ON HIGHER EDUCATION AROUND THE WORLD (IAU Global Survey Report, Issue. I. A. o. Universities. https://www.iauaiu.net/IMG/pdf/iau_covid19_and_he_survey_report_final_may_2020.pdf

Marshall, G. (2005). The purpose, design and administration of a questionnaire for data collection. Radiography, 11(2), 131-136. https://doi.org/10.1016/j.radi.2004.09.002

Mishra, L., Gupta, T., \& Shree, A. (2020). Online teaching-learning in higher education during lockdown period of COVID-19 pandemic. International Journal of Educational Research Open, 1, 100012. https:/ / doi.org/10.1016/j.ijedro.2020.100012

Mödritscher, F. (2006). E-learning theories in practice: A comparison of three methods. Journal of Universal Science and Technology of Learning, 28(1), 3-18. http://www.jucs.org/justl_0_0/elearning_theories_in_practice/justl_0_0_0003_ 0018_moedritscher.html

Motte-Signoret, E., Labbe, A., Benoist, G., Linglart, A., Gajdos, V., \& Lapillonne, A. (2021). Perception of medical education by learners and teachers during the COVID-19 pandemic: a cross-sectional survey of online teaching. Med Educ Online, 26(1), 1919042. https://doi.org/10.1080/10872981.2021.1919042

Nasiri, F., Ghanbari, S., Ardalan, M., \& Karimi, I. (2014). Effect of infrastructure and faculty readiness in effective implementation of e-Learning based on Technology Acceptance Model (TAM). Education Strategies in Medical Sciences, 7(5), 329-328. http:/ / edcbmj.ir/article-1-692-en.html 
Naveed, Q. N., Muhammad, A., Sanober, S., Qureshi, M. R. N., \& Shah, A. (2017). A mixed method study for investigating critical success factors (CSFs) of e-learning in Saudi Arabian universities. International Journal of Advanced Computer Science and Applications, https:// pdfs.semanticscholar.org/19e8/f66075ed339990572c135e8c13a9a9df3af0 .pdf

Parandeh, A., Khaghanizade, M., Mohammadi, E., \& Nouri, J. M. (2015). Factors influencing development of professional values among nursing students and instructors: a systematic review. Global journal of health science, 7(2), 284. https://doi.org/10.5539/gihs.v7n2p284

PNU. (2020). College of Health and Rehabilitation Sciences. Retrieved 15th April 2020 from https://www.pnu.edu.sa/en/Faculties/Health-

Rehabilitation/Pages/Home.aspx

Pottle, J. (2019). Virtual reality and the transformation of medical education. Future healthcare journal, 6(3), 181. https://doi.org/10.7861/fhj.2019-0036

Rajab, K. D. (2018). The effectiveness and potential of E-learning in war zones: An empirical comparison of face-to-face and online education in Saudi Arabia. IEEE Access, 6, 6783-6794. https://doi.org/10.1109/ACCESS.2018.2800164

Rice, S., \& McKendree, J. (2014). e-Learning. In T. Swanwick (Ed.), Understanding medical education : evidence, theory and practice. Wiley-Blackwell.

Saddik, B., Hussein, A., Sharif-Askari, F. S., Kheder, W., Temsah, M.-H., Koutaich, R. A., Haddad, E. S., Al-Roub, N. M., Marhoon, F. A., \& Hamid, Q. (2020). Increased levels of anxiety among medical and non-medical university students during the COVID-19 pandemic in the United Arab Emirates. Risk Manag Healthc Policy, 3, 2395-2406. https://doi.org/10.2147/RMHP.S273333

Sajid, M. R., Laheji, A. F., Abothenain, F., Salam, Y., AlJayar, D., \& Obeidat, A. (2016). Can blended learning and the flipped classroom improve student learning and satisfaction in Saudi Arabia? International journal of medical education, 7, 281-285. https://doi.org/10.5116/ijme.57a7.83d4

Skochelak, S. E., \& Stack, S. J. (2017). Creating the medical schools of the future. Academic Medicine, 92(1), 16-19. https:// doi.org/10.1097/ ACM.0000000000001160

Sørebø, A. M., \& Sørebø, Ø. (2008). Understanding e-learning satisfaction in the context of university teachers. World Academy of Science, Engineering and Technology, 46, 7275.

Uttl, B., White, C. A., \& Gonzalez, D. W. (2017). Meta-analysis of faculty's teaching effectiveness: Student evaluation of teaching ratings and student learning are not related. Studies in Educational Evaluation, 54, 22-42. https:// doi.org/10.1016/j.stueduc.2016.08.007

Van Merrienboer, J. J., \& Ayres, P. (2005). Research on cognitive load theory and its design implications for e-learning. Educational Technology Research and Development, 53(3), 5-13. https://link.springer.com/content/pdf/10.1007/BF02504793.pdf

Wei, H.-C., \& Chou, C. (2020). Online learning performance and satisfaction: do perceptions and readiness matter? Distance Education, 41(1), 48-69. https://doi.org/10.1080/01587919.2020.1724768

Yang, Y., \& Cao, L. (2013). Differential influences of achievement approach goals and intrinsic/extrinsic motivation on help-seeking in e-learning. Knowledge Management \& E-Learning: An International Journal, 5(2), 153-169. https://doi.org/10.34105/j.kmel.2013.05.011

Yengin, I., Karahoca, A., \& Karahoca, D. (2011). E-learning success model for instructors' satisfactions in perspective of interaction and usability outcomes. Procedia Computer Science, 3, 1396-1403. https://doi.org/10.1016/j.procs.2011.01.021 
Zakaria, N., Jamal, A., Bisht, S., \& Koppel, C. (2013). Embedding a learning management system into an undergraduate medical informatics course in Saudi Arabia: lessons learned. Medicine 2.0, 2(2), e13-e13. https://doi.org/10.2196/med20.273

\section{Appendix 1}

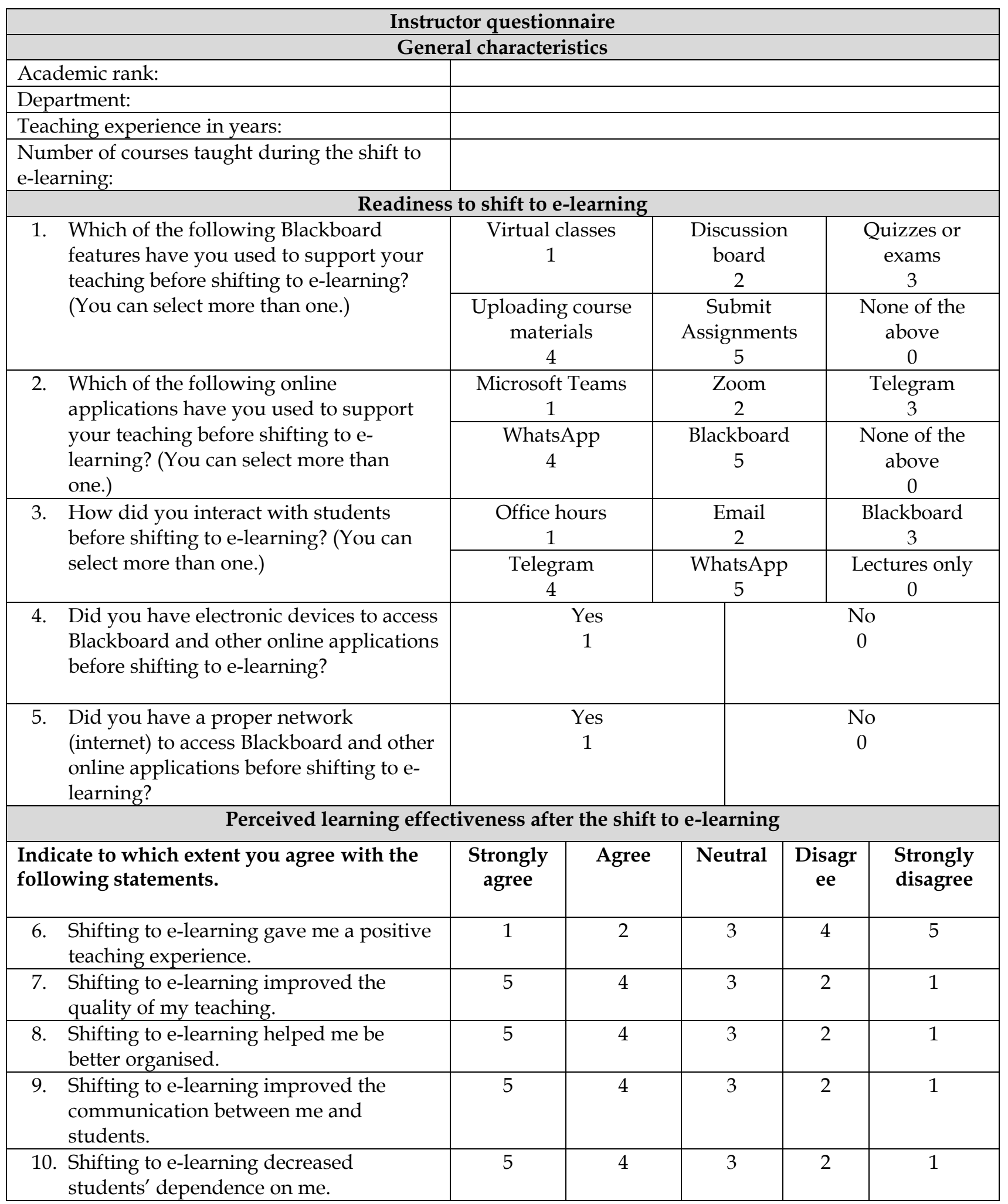




\begin{tabular}{|l|c|c|c|c|c|}
\hline $\begin{array}{l}\text { 11. Shifting to e-learning helped me work at } \\
\text { my own speed. }\end{array}$ & 5 & 4 & 3 & 2 & 1 \\
\hline $\begin{array}{l}\text { 12. Shifting to e-learning enabled me to } \\
\text { achieve course learning outcomes. }\end{array}$ & 5 & 4 & 3 & 2 & 1 \\
\hline $\begin{array}{l}\text { 13. Shifting to e-learning introduced me to } \\
\text { different online applications which } \\
\text { helped my teaching. }\end{array}$ & 5 & 4 & 3 & 2 & 1 \\
\hline $\begin{array}{l}\text { 14. Shifting to e-learning introduced me to a } \\
\text { variety of assessment methods. }\end{array}$ & 5 & 4 & 3 & 2 & 1 \\
\hline $\begin{array}{l}\text { 15. Shifting to e-learning helped me manage } \\
\text { my time more effectively. }\end{array}$ & 5 & 4 & 3 & 2 & 1 \\
\hline $\begin{array}{l}\text { 16. Shifting to e-learning was a good } \\
\text { motivation to use different teaching } \\
\text { styles. }\end{array}$ & 5 & 4 & 3 & 2 & 1 \\
\hline $\begin{array}{l}\text { 17. Shifting to e-learning helps deliver } \\
\text { subject material well. }\end{array}$ & 5 & 4 & 3 & 2 & 1 \\
\hline $\begin{array}{l}\text { 18. Shifting to e-learning is more enjoyable } \\
\text { than face-to-face learning. }\end{array}$ & 5 & 4 & 3 & 2 & 1 \\
\hline $\begin{array}{l}\text { 19. Shifting to e-learning made me prefer to } \\
\text { teach more courses through remote } \\
\text { learning. }\end{array}$ & 5 & 4 & 3 & 2 & 1 \\
\hline & & & & & \\
\hline $\begin{array}{l}\text { Overall, during the shift to e-learning, how } \\
\text { satisfied are you with: }\end{array}$ & $\begin{array}{l}\text { Strongly } \\
\text { satisfied }\end{array}$ & Satisfied & Neutral & Unsati \\
\hline 20. The e-learning experience? & 5 & 4 & 3 & 2 & Strongly \\
\hline 21. The clarity of e-learning instructions? & 5 & 4 & 3 & 2 & 1 \\
\hline 22. The accessibility of e-learning materials? & 5 & 4 & 3 & 2 & 1 \\
\hline 23. The simplicity of e-learning tools? & 5 & 4 & 3 & 2 & 1 \\
\hline $\begin{array}{l}\text { 24. The support received during remote } \\
\text { teaching? }\end{array}$ & 5 & 4 & 3 & 2 & 1 \\
\hline
\end{tabular}




\section{Appendix 2}

\begin{tabular}{|c|c|c|c|c|c|}
\hline \multicolumn{6}{|c|}{ Student questionnaire } \\
\hline \multicolumn{6}{|c|}{ General characteristics } \\
\hline \multicolumn{6}{|l|}{ Age: } \\
\hline \multicolumn{6}{|l|}{ Department: } \\
\hline \multicolumn{6}{|l|}{ Level of study: } \\
\hline \multicolumn{6}{|l|}{ GPA: } \\
\hline \multicolumn{6}{|c|}{ Readiness to shift to e-learning } \\
\hline \multirow{2}{*}{$\begin{array}{l}\text { Which of the following } \\
\text { Blackboard features have } \\
\text { you experienced before } \\
\text { shifting to e-learning? (You } \\
\text { can select more than one.) }\end{array}$} & \multicolumn{2}{|c|}{$\begin{array}{c}\text { Virtual classes } \\
1\end{array}$} & \multicolumn{2}{|c|}{$\begin{array}{l}\text { Discussion board } \\
2\end{array}$} & $\begin{array}{c}\text { Quizzes or exams } \\
3\end{array}$ \\
\hline & \multicolumn{2}{|c|}{$\begin{array}{c}\text { Downloading course } \\
\text { materials } \\
4\end{array}$} & \multicolumn{2}{|c|}{$\begin{array}{l}\text { Submitting } \\
\text { assignments } \\
5\end{array}$} & $\begin{array}{c}\text { None of the above } \\
0\end{array}$ \\
\hline \multirow{2}{*}{$\begin{array}{l}\text { Which of the following } \\
\text { online applications have you } \\
\text { used to support your } \\
\text { learning before shifting to e- } \\
\text { learning? (You can select } \\
\text { more than one.) }\end{array}$} & \multicolumn{2}{|c|}{$\begin{array}{c}\text { Microsoft Teams } \\
1 \\
\end{array}$} & \multicolumn{2}{|c|}{$\begin{array}{l}\text { Zoom } \\
\quad 2\end{array}$} & $\begin{array}{l}\text { Telegram } \\
\quad 3\end{array}$ \\
\hline & \multicolumn{2}{|c|}{$\begin{array}{l}\text { WhatsApp } \\
\quad 4\end{array}$} & \multicolumn{2}{|c|}{$\begin{array}{l}\text { Blackboard } \\
5\end{array}$} & $\begin{array}{c}\text { None of the above } \\
0\end{array}$ \\
\hline \multirow{2}{*}{$\begin{array}{ll}\text { 3. } & \text { How did you interact with } \\
\text { course instructors before } \\
\text { shifting to e-learning? (You } \\
\text { can select more than one.) }\end{array}$} & \multicolumn{2}{|c|}{$\begin{array}{c}\text { Office hours } \\
1 \\
\end{array}$} & \multicolumn{2}{|c|}{$\begin{array}{c}\text { Email } \\
2\end{array}$} & $\begin{array}{c}\text { Blackboard } \\
3\end{array}$ \\
\hline & \multicolumn{2}{|c|}{$\begin{array}{l}\text { Telegram } \\
4\end{array}$} & \multicolumn{2}{|c|}{$\begin{array}{l}\text { WhatsApp } \\
5\end{array}$} & $\begin{array}{c}\text { Limited to lectures } \\
0 \\
\end{array}$ \\
\hline $\begin{array}{l}\text { 4. Did you have electronic } \\
\text { devices to access Blackboard } \\
\text { and other online } \\
\text { applications before shifting } \\
\text { to e-learning? }\end{array}$ & \multicolumn{4}{|c|}{$\begin{array}{c}\text { Yes } \\
1\end{array}$} & $\begin{array}{c}\text { No } \\
0\end{array}$ \\
\hline $\begin{array}{l}\text { 5. Did you have a proper } \\
\text { network (internet) to access } \\
\text { Blackboard and other online } \\
\text { applications before shifting } \\
\text { to e-learning? }\end{array}$ & \multicolumn{2}{|r|}{$\begin{array}{l}\text { Yes } \\
1\end{array}$} & & & $\begin{array}{c}\text { No } \\
0\end{array}$ \\
\hline \multicolumn{6}{|c|}{ Perceived learning effectiveness after the shift to e-learning } \\
\hline $\begin{array}{l}\text { Indicate to which extent you agree } \\
\text { with the following statements. }\end{array}$ & $\begin{array}{c}\text { Strongly } \\
\text { agree }\end{array}$ & Agree & Neutral & Disagree & Strongly disagree \\
\hline $\begin{array}{l}\text { 6. Shifting to e-learning gave } \\
\text { me a positive learning } \\
\text { experience. }\end{array}$ & 5 & 4 & 3 & 2 & 1 \\
\hline $\begin{array}{l}\text { 7. Shifting to e-learning } \\
\text { improved the quality of my } \\
\text { studies. }\end{array}$ & 5 & 4 & 3 & 2 & 1 \\
\hline $\begin{array}{l}\text { 8. Shifting to e-learning helped } \\
\text { me be better organised. }\end{array}$ & 5 & 4 & 3 & 2 & 1 \\
\hline $\begin{array}{l}\text { 9. Shifting to e-learning } \\
\text { improved the }\end{array}$ & 5 & 4 & 3 & 2 & 1 \\
\hline
\end{tabular}




\begin{tabular}{|c|c|c|c|c|c|c|}
\hline & $\begin{array}{l}\text { communication between me } \\
\text { and the course instructor. }\end{array}$ & & & & & \\
\hline & $\begin{array}{l}\text { Shifting to e-learning helped } \\
\text { me become an independent } \\
\text { learner/ }\end{array}$ & 5 & 4 & 3 & 2 & 1 \\
\hline & $\begin{array}{l}\text { Shifting to e-learning helped } \\
\text { me work at my own speed. }\end{array}$ & 5 & 4 & 3 & 2 & 1 \\
\hline & $\begin{array}{l}\text { Shifting to e-learning helped } \\
\text { in my knowledge and skills } \\
\text { development. }\end{array}$ & 5 & 4 & 3 & 2 & 1 \\
\hline & $\begin{array}{l}\text { Shifting to e-learning } \\
\text { introduced me to different } \\
\text { online applications which } \\
\text { helped my learning. }\end{array}$ & 5 & 4 & 3 & 2 & 1 \\
\hline 14. & $\begin{array}{l}\text { Shifting to e-learning } \\
\text { introduced me to a variety of } \\
\text { assessment methods which } \\
\text { affected my learning in a } \\
\text { positive way. }\end{array}$ & 5 & 4 & 3 & 2 & 1 \\
\hline 15. & $\begin{array}{l}\text { Shifting to e-learning helped } \\
\text { me manage my time more } \\
\text { effectively. }\end{array}$ & 5 & 4 & 3 & 2 & 1 \\
\hline 16. & $\begin{array}{l}\text { Shifting to e-learning was a } \\
\text { good motivation for } \\
\text { learning. }\end{array}$ & 5 & 4 & 3 & 2 & 1 \\
\hline 17. & $\begin{array}{l}\text { Shifting to e-learning helped } \\
\text { me understand the subject's } \\
\text { material well. }\end{array}$ & 5 & 4 & 3 & 2 & 1 \\
\hline 18. & $\begin{array}{l}\text { Shifting to e-learning is more } \\
\text { enjoyable than face-to-face } \\
\text { learning. }\end{array}$ & 5 & 4 & 3 & 2 & 1 \\
\hline & $\begin{array}{l}\text { Shifting to e-learning made } \\
\text { me prefer to have more } \\
\text { courses delivered through } \\
\text { remote learning. }\end{array}$ & 5 & 4 & 3 & 2 & 1 \\
\hline \multicolumn{7}{|c|}{ Satisfaction } \\
\hline $\begin{array}{l}\text { Overall } \\
\text { learnin } \\
\text { with: }\end{array}$ & $\begin{array}{l}\text { 11, during the shift to e- } \\
\text { ng, how satisfied are you }\end{array}$ & $\begin{array}{l}\text { Strongly } \\
\text { satisfied }\end{array}$ & $\begin{array}{l}\text { Satisfie } \\
\quad \mathrm{d}\end{array}$ & Neutral & $\begin{array}{l}\text { Unsatisfi } \\
\text { ed }\end{array}$ & Strongly unsatisfied \\
\hline 20. & The e-learning experience? & 5 & 4 & 3 & 2 & 1 \\
\hline 21. & $\begin{array}{l}\text { The clarity of e-learning } \\
\text { instructions? }\end{array}$ & 5 & 4 & 3 & 2 & 1 \\
\hline 22. & $\begin{array}{l}\text { The accessibility of e- } \\
\text { learning materials? }\end{array}$ & 5 & 4 & 3 & 2 & 1 \\
\hline 23. & $\begin{array}{l}\text { The simplicity of e- } \\
\text { learning tools? }\end{array}$ & 5 & 4 & 3 & 2 & 1 \\
\hline 24. & $\begin{array}{l}\text { Instructors' feedback during } \\
\text { e-learning? }\end{array}$ & 5 & 4 & 3 & 2 & 1 \\
\hline
\end{tabular}

